\title{
Correction to: Gender, Race, and Intersectionality in Campaign Finance
}

\author{
Jacob M. Grumbach ${ }^{1} \cdot$ Alexander Sahn $^{2} \cdot$ Sarah Staszak $^{3}$
}

Published online: 10 March 2021

○) Springer Science+Business Media, LLC, part of Springer Nature 2021

\section{Correction to: Political Behavior https://doi.org/10.1007/s11109-020-09619-0}

The original version of this article unfortunately contained a citation error in the introduction. The article has been corrected in the current version.

Incorrect: there is yet no estimate of the joint ethnora2019ce-gender distribution of campaign

Correct: there is yet no estimate of the joint ethnorace-gender distribution of campaign

Publisher's Note Springer Nature remains neutral with regard to jurisdictional claims in published maps and institutional affiliations.

The original article can be found online at https://doi.org/10.1007/s11109-020-09619-0.

Jacob M. Grumbach

jakegrumbach@gmail.com; grumbach@uw.edu

1 University of Washington, Seattle, USA

2 University of California, Berkeley, Berkeley, USA

3 Princeton University, Princeton, USA 